\title{
Taking/receiving and giving (TRG): A comparison of two quantitative pilot studies on students' entrepreneurial motivation in Indonesia
}

Purwana, Dedi

Faculty of Economics, Universitas Negeri Jakarta, Indonesia (deagina@yahoo.com)

Suhud, Usep $\bowtie$

Faculty of Economics, Universitas Negeri Jakarta, Indonesia (usepsuhud@feunj.ac.id)

Arafat, Yasser M.

Faculty of Economics, Universitas Negeri Jakarta, Indonesia (yasser@feunj.ac.id)

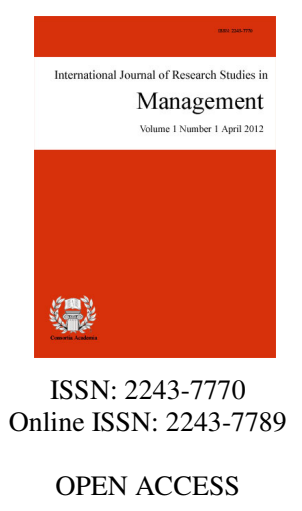

Received: 4 October 2014

Revised: 18 November 2014

Available Online: 18 January 2015 DOI: $10.5861 /$ ijrsm.2015.1004

\section{Abstract}

The objective of this study is to understand university students' entrepreneurial motivation between two groups with different backgrounds. The authors examines whether taking/receiving and giving (TRG) motivation is applicable. A qualitative study was conducted to explore ideas relating entrepreneurial motivation and the results were adapted into quantitative indicators. To validate the quantitative instrument, the authors chose two different groups: the first group consists of students with entrepreneurial education and the second group consists of students without an entrepreneurial education. For the qualitative study, data were collected using projective technique and analyzed using content analysis. For the quantitative studies, data were collected through online surveys and analyzed using exploratory and confirmatory (structural equation model) analyses. As a result, TRG motivation works on samples with an entrepreneurial education whereas intrinsic and extrinsic motivation works for samples without an entrepreneurial education.

Keywords: entrepreneurial motivation; projective technique; exploratory and confirmatory factor analyses; structural equation model; Indonesia 


\section{Taking/receiving and giving (TRG): A comparison of two quantitative pilot studies on students' entrepreneurial motivation in Indonesia}

\section{Introduction}

The objective of this study is to explore university students' entrepreneurial motivation between two groups with different backgrounds (with and without an entrepreneurial education) in Indonesia. By knowing this, universities, government, or other parties who have a concern on entrepreneurial education, may design an entrepreneurial programs to attract students to be a young entrepreneur. Many studies showed that entrepreneurial education increased students' motivation and intention to be an entrepreneur (Bellotti et al., 2014; Duval-Couetil, 2013; Karimi, Biemans, Lans, Chizari, \& Mulder, 2014; Piperopoulos \& Dimov, 2014; Solesvik, 2013).

According to the Bureau of Statistics (2012), up to 2012, there were 56.534.592 micro, small, and medium sized enterprises in Indonesia. This number is considered low comparing to the total population. Therefore, the government promotes entrepreneurship and encourages housewives, employees, and particularly university students to be an entrepreneur. Generally, the promotion includes courses, seminars, workshops, and competitions. Using data from two quantitative pilot studies, the aim of this study is to understand students' entrepreneurial motivation using two groups of samples: first group was those who had entrepreneurship education and second group was those who had not have entrepreneurship education.

\section{Literature review}

In conducting studies on students' entrepreneurial motivation, researchers used and resulted different approaches including pull and push (De Silva, 2010), achievement (Gamage, Cameron, \& Woods, 2003; Shane, Locke, \& Collins, 2003; Ullah, 2011), employed and self-employed (Berthold \& Neumann, 2008; Jones, Beynon, Pickernell, \& Packham, 2013), and extrinsic and intrinsic (Kauanui, Ashley-Cotleur, \& Solomon, 2003) motivations. Extrinsic motivations are inner motivations that are influenced by individuals whereas intrinsic motivations are motivations that are influenced by outer of those individuals (Kompf, 2012).

Another approach that has never been applied in entrepreneurial study is taking/receiving and giving (TRG) motivation. TRG motivation was applied by Suhud (2014) on volunteer tourism. Based on his findings, motivation is not a single variable. Using a mixed-methods study, he found that motivation should be divided into taking/receiving motivation and giving motivation variables. Suhud (2014) mentioned that to be involved in volunteer tourism, volunteer tourists and potential volunteer tourists were motivated by taking/receiving motivation, as representative of motivation in tourism and giving motivation, as representative of motivation in volunteerism and volunteer tourism.

The authors are interested in applying this TRG as there are found indicators on entrepreneurial motivation indicating taking/receiving motivation variable, such as "to increase my income", "to prove I can do it", and "to be my own boss" (Benzing, Chu, \& Kara, 2009; Keat \& Ahmad, 2012; Robichaud, Cachon, \& Haq, 2010; Stefanović, Ranković, \& Prokić, 2011). This variable shows individuals' egoistic and self-interest aspects. On the other hand, some other indicators, such as "to provide jobs for family members" and "to provide employment" (Fatoki \& Patswawairi, 2012; Robichaud et al., 2010; Samuel, Ernest, \& Awuah, 2013; Zimmerman \& Chu, 2013) indicate to be part of giving motivation variable. This variable shows individuals' altruistic aspects. 


\section{Methodology}

This is a mixed-methods study with the qualitative approach was in the first step and followed by two pilot studies.

\subsection{The qualitative study}

For the qualitative study, data were collected using a projective technique (Catterall \& Ibbotson, 2000; Donoghue, 2000). The authors asked a question about participants' motivation to be an entrepreneur and they wrote down the answer on sticky note paper for each idea of answers. On the wall, the authors hung a giant poster of human anatomy. Furthermore, the participants sticked the sticky note paper on the poster and adjusted to the parts of the anatomy - head, breast, stomach, legs, hands, and genital area. This activity stimulated participants to be more productive resulting ideas of answers. In total, there were 65 (38 female and 27 male) university students who had an entrepreneurial education who joined the research. This qualitative step was conducted in September 2013.

\subsection{The quantitative pilot studies}

For the quantitative pilot studies, data were collected using online surveys. The authors invited participants into a computer room and through an email gave them a link to the web-based online questionnaire. The participants filled in the questionnaire and the authors obtained the feedbacks right away in the room. All data collections were conducted within November 2013. Of the first pilot study, 68 university students who had an entrepreneurial education participated, consisted of 46 female and 22 male students. In addition, 65 participants were Muslims, 14 of them ran a business, and 23 of them had a parent ran a business. Of the second pilot study, 185 (130 female and 55 male) students who had no an entrepreneurial education responded the invitation to join the research. Again, Islam was the predominant religion of the participants (170) and 59 of all ran their own business and 57 of them had a parent ran a business. A question relating religion was intentionally addressed as inspired by the qualitative findings.

\section{Findings}

\subsection{The qualitative study findings}

The authors obtained 202 keywords relating to students' entrepreneurial motivation and adapted each of them into an indicator for the quantitative study instrument. As mentioned earlier, the authors used only indicators produced by the qualitative study. However, after observing the results and literature, the authors found that some indicators are similar with indicators used by many researchers before. These indicators include "to be my own boss", to realise my dream", and "to increase my social status". Furthermore, these similar indicators below are included in many studies undertaken by Gray, Foster, and Howard (2006), Osman et al. (2010), Samuel et al., 2013, Neneh (2014), Gray et al. (2006), Stanley (1987), Keat and Ahmad (2012), Singh (1993), Zimmerman and Chu (2013), Benzing et al. (2009), Fatoki (2010), Fatoki and Patswawairi (2012), (Basu and Altinay (2002), Karimi et al. (2014), Ullah (2011), and Zhu and Chu (2010).

\section{Table 1}

Indicators that similar with the ones that have been used by other researchers

\begin{tabular}{ll}
\hline & Adapted indicators \\
\hline Cannot work for others. & Opportunities in the market \\
Encouraged by a friend. & Opportunity to offer employment to others To allow \\
Family business. & for early retirement. \\
I like taking risk. & To be innovative by developing new ideas. \\
Interest in subject. & To be my own boss. \\
\hline
\end{tabular}


Table 2 ... continued

\begin{tabular}{ll}
\hline & Adapted indicators \\
\hline To become independent. & To obtain my personal growth. \\
To become wealthy. & To prove I can do it. \\
To build a business to pass on. & To provide employment. \\
To compete with others. & To provide job security. \\
To reduce poverty. & To pursue my own interest. \\
To develop new ideas. & To realise my dream. \\
To earn a reasonable living & To respond to change. \\
To earn more money. & To result of my financial security. \\
To gain public recognition. & To support my family. \\
To have my personal freedom. & To take advantage of my creative talent. \\
To increase my social status. & To use the skill learned in the university. \\
To meet the challenge. & \\
\hline
\end{tabular}

Furthermore, the Table 2 below shows some unique indicators that have never been used by other researchers.

\section{Table 2}

Unique indicators that never have been used by other researchers

\begin{tabular}{ll}
\hline & Adapted indicators \\
\hline Being an entrepreneur is cool. & To have many friends. \\
Don't have to work for other people. & To get my financial freedom at the age of 30. \\
Don't look for a job but provide a job. & To give other people. \\
Don't want to be managed by other people. & To go to the pilgrimage of hajj using my own \\
For the wealthy of the society. & money. \\
Inspired by my parent. & To have a better future. \\
To be an entrepreneurial motivator. & To have a vision and mission. \\
To be discipline with time. & To employ people. \\
To be like Mohammad the prophet having own & To make my live be more stable. \\
business. & To make my parent proud. \\
To be proud by having my own business. & To make my parent/family happy. \\
To be successful more than my parent. & To motivate people to be a successful \\
To be useful for others. & entrepreneur. \\
To buy my parent a house. & To obtain a proper life. \\
To continue studying overseas. & To obtain a good name. \\
To contribute to my country. & To promote the good name of Islam. \\
To decrease the number of jobless people. & To realise my hope. \\
To ease other people's lives. & To realise my pray. \\
To enjoy my later life with a financial problem. & To share with street kids. \\
To enrich myself with experiences. & To socialise with other people. \\
To exercise to be more creative. & To stimulate my brain to get brilliant ideas. \\
To get a wide business network. & To support government's programs. \\
To get everything I want. & To take advantage of my background. \\
To have flexible time. & To take my parent to the pilgrimage of hajj. \\
To get married in the young age. & To travel overseas. \\
\hline
\end{tabular}

\subsection{The quantitative pilot study \#1}

Exploratory factor analysis - Exploratory factor analysis is used in this work as a way to validate the indicators, dimensions, and variables (Holmes-Smith, 2010). As a result, 40 indicators retain during the analysis. These indicators survive under 11 dimensions, including 'safety' (factor loadings ranging from 0.646 to 0.806), 'family' (factor loadings ranging from 0.687 to -0.902), 'religious' (factor loadings ranging from -0.561 to -0.995), 'independent' (factor loadings ranging from 0.701 to 0.887 ), 'public service' (factor loadings ranging from 0.549 to 0.889 ), 'self-development' (factor loadings ranging from 0.800 to 0.862 ), 'creative' (factor loadings ranging from 0.493 to 0.834 ), 'parent' (factor loadings ranging from -0.675 to -0.797), 'nationalistic' (factor loadings ranging from 0.605 to 0.619 ), 'hope' (factor loadings ranging from 0.802 to 0.914 ), and 'time 
Taking/receiving and giving: A comparison of two studies on students' entrepreneurial motivation in Indonesia flexibility' (factor loadings ranging from 0.430 to 0.782 ) motivations (please see Table 3). In general, Cronbach's alpha score of the first pilot study from all dimensions ranging from 0.630 (family motivation dimension) to 0.943 (religious motivation dimension) (please see Table 3) and all dimensions are considered reliable. According to Nunnally and Bernstein (1994), the acceptable score for a reliability test should be 0.6 and greater.

Table 3

Results of exploratory factor analysis of the first pilot study and reliability tests

\begin{tabular}{|c|c|c|c|c|c|c|c|c|c|c|c|c|}
\hline \multicolumn{13}{|c|}{ Indicators } \\
\hline 1 & $\begin{array}{l}\text { Safety motivation } \\
\end{array}$ & 1 & 2 & 3 & 4 & 5 & 6 & 7 & 8 & 9 & 10 & 11 \\
\hline Q7-30 & To increase my social status. & 0.806 & & & & & & & & & & \\
\hline Q8-22 & To result of my financial security. & 0.761 & & & & & & & & & & \\
\hline Q8-24 & To make my live be more stable. & 0.732 & & & & & & & & & & \\
\hline \multirow[t]{2}{*}{ Q9-4 } & To provide job security. & 0.646 & & & & & & & & & & \\
\hline & Cronbach's alpha & 0.881 & & & & & & & & & & \\
\hline \multicolumn{13}{|c|}{ Family motivation } \\
\hline Q3-40 & To make my parent proud. & & -0.902 & & & & & & & & & \\
\hline Q3-29 & To support my family. & & -0.850 & & & & & & & & & \\
\hline Q3-32 & To buy my parent a house. & & -0.821 & & & & & & & & & \\
\hline Q3-16 & To be successful more than my parent. & & -0.779 & & & & & & & & & \\
\hline Q5-9 & To have a better future. & & -0.743 & & & & & & & & & \\
\hline \multirow[t]{2}{*}{ Q7-26 } & To enjoy my later life without a financial problem. & & -0.687 & & & & & & & & & \\
\hline \multirow{2}{*}{\multicolumn{13}{|c|}{$\begin{array}{l}\text { Cronbach's alpha } \\
\text { Religious motivation }\end{array}$}} \\
\hline & & & & & & & & & & & & \\
\hline Q6-2 & To take my parent to go to the pilgrimage of hajj. & & & -0.995 & & & & & & & & \\
\hline Q9-11 & To go to the pilgrimage of hajj using my own money. & & & -0.977 & & & & & & & & \\
\hline Q3-9 & To be like Muhammad the prophet having own business. & & & -0.851 & & & & & & & & \\
\hline Q6-25 & To promote the good name of Islam & & & -0.817 & & & & & & & & \\
\hline \multirow{2}{*}{ Q10-28 } & 3 The Prophet's 'sunnah'. & & & -0.561 & & & & & & & & \\
\hline & Cronbach's alpha & & & 0.943 & & & & & & & & \\
\hline 4 & Independent motivation & & & & & & & & & & & \\
\hline \multirow{5}{*}{$\begin{array}{l}\text { Q10-12 } \\
\text { Q10-13 } \\
\text { Q10-18 } \\
\text { Q10-17 }\end{array}$} & 2 Can't work for other people. & & & & 0.887 & & & & & & & \\
\hline & 3 Don't want to be managed by other people. & & & & 0.885 & & & & & & & \\
\hline & Don't have to work for other people. & & & & 0.718 & & & & & & & \\
\hline & 7 Don't search, but provide a job. & & & & 0.701 & & & & & & & \\
\hline & Cronbach's alpha & & & & 0.835 & & & & & & & \\
\hline 5 & Public service motivation & & & & & & & & & & & \\
\hline \multirow{5}{*}{$\begin{array}{c}\text { Q6-1 } \\
\text { Q7-8 } \\
\text { Q12-25 } \\
\text { Q3-36 }\end{array}$} & To ease other people's lives. & & & & & 0.889 & & & & & & \\
\hline & To eliminate poverty. & & & & & 0.762 & & & & & & \\
\hline & 5 To share with street kids. & & & & & 0.639 & & & & & & \\
\hline & To support my country. & & & & & 0.549 & & & & & & \\
\hline & Cronbach's alpha & & & & & 0.797 & & & & & & \\
\hline 6 & Self-development motivation & & & & & & & & & & & \\
\hline & To obtain my personal growth. & & & & & & 0.862 & & & & & \\
\hline Q3-4 & To be useful for others. & & & & & & 0.800 & & & & & \\
\hline & Cronbach's alpha & & & & & & 0.708 & & & & & \\
\hline 7 & Creative motivation & & & & & & & & & & & \\
\hline Q3-20 & To exercise to be more creative. & & & & & & & 0.834 & & & & \\
\hline Q3-21 & To stimulate my brain to get brilliant ideas. & & & & & & & 0.791 & & & & \\
\hline Q6-3 & To be a business motivator. & & & & & & & 0.493 & & & & \\
\hline & Cronbach's alpha & & & & & & & 0.707 & & & & \\
\hline 8 & Parent's role motivation & & & & & & & & & & & \\
\hline Q12-4 & Get inspired by my parent. & & & & & & & & -0.797 & & & \\
\hline Q12-5 & Being an entrepreneur is cool. & & & & & & & & -0.675 & & & \\
\hline & Cronbach's alpha & & & & & & & & 0.650 & & & \\
\hline 9 & Nationalistic motivation & & & & & & & & & & & \\
\hline Q7-19 & To reduce poverty. & & & & & & & & & 0.619 & & \\
\hline Q3-24 & To build a business to pass on. & & & & & & & & & 0.610 & & \\
\hline Q12-3 & For the wealthy of society. & & & & & & & & & 0.605 & & \\
\hline & Cronbach's alpha & & & & & & & & & 0.781 & & \\
\hline 10 & Hope motivation & & & & & & & & & & & \\
\hline Q10-21 & To realise my hope. & & & & & & & & & & 0.914 & \\
\hline Q8-5 & To be my own boss. & & & & & & & & & & 0.802 & \\
\hline & Cronbach's alpha & & & & & & & & & & 0.721 & \\
\hline 11 & Time flexibility motivation & & & & & & & & & & & \\
\hline Q10-25 & 5 To take advantage from my life background. & & & & & & & & & & & 0.782 \\
\hline Q10-7 & I like taking risk & & & & & & & & & & & 0.697 \\
\hline Q5-21 & To have flexible time. & & & & & & & & & & & 0.526 \\
\hline Q12-29 & To be discipline with time. & & & & & & & & & & & 0.470 \\
\hline Q7-6 & To use the skill learned in the university. & & & & & & & & & & & 0.430 \\
\hline & Cronbach's alpha & & & & & & & & & & & 0.782 \\
\hline
\end{tabular}




\subsection{Confirmatory factor analysis}

Hair Jr. et al. (2006) mention that to calculate structural equation modelling, it requires at least 150 sample to avoid failure in calculation. However, even though in this first pilot study only 68 samples involved, the authors insisted to use this tool to examine the data. As a result, two fitted constructs were succeeded to be developed. The first construct illustrates the first variable of motivation and it considers as taking/receiving motivation. This variable owns three dimensions - 'safety' with four indicators, 'creativity' with two indicators and 'time flexibility' with four indicators. This construct fits with probability score of 0.399, CMIN/DF of 1.044, CFI of 0.996 , and RMSEA of 0.026 .

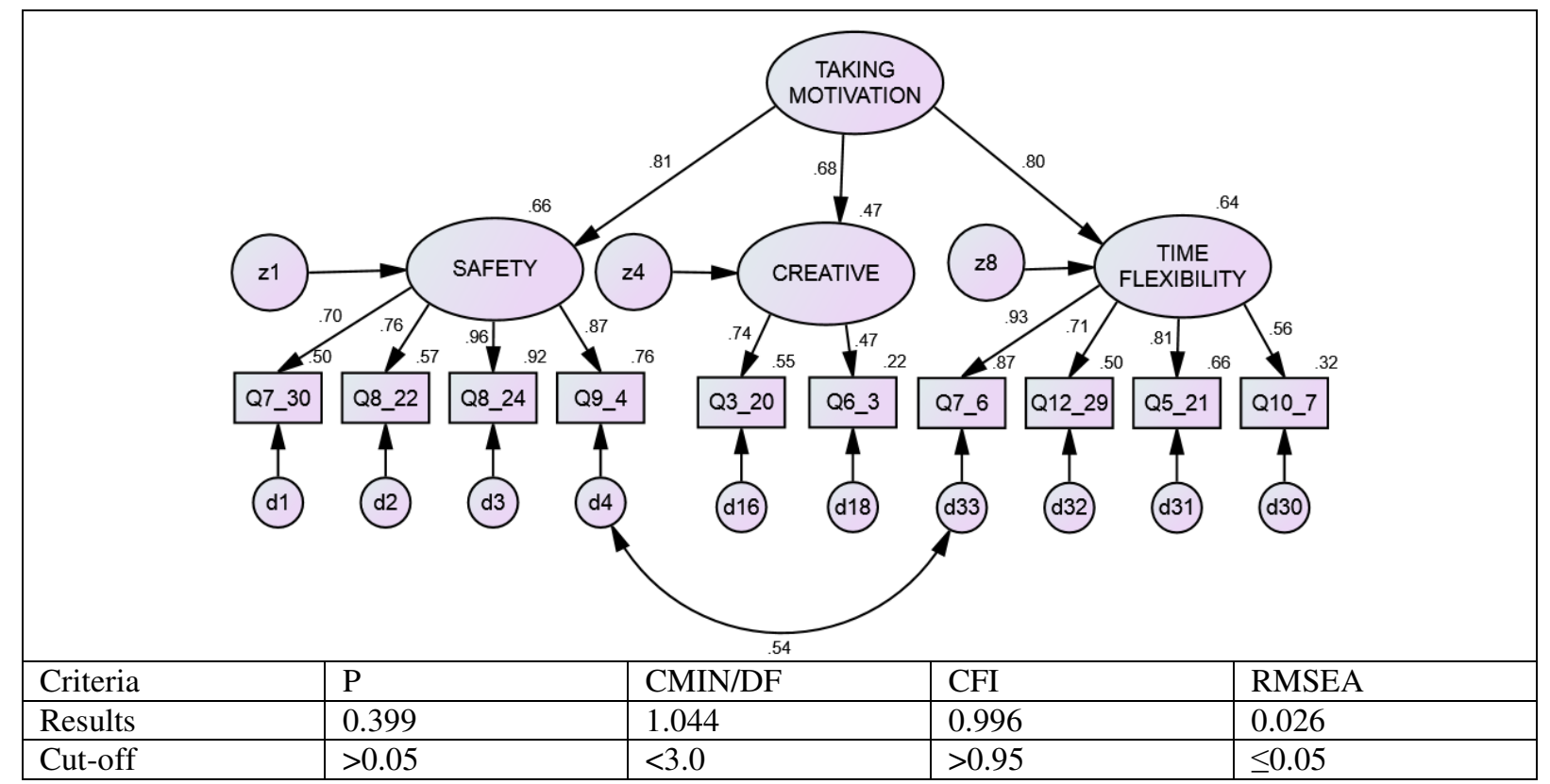

Figure 1. The fitted construct of taking/receiving motivation

The second construct below shows giving motivation variable with three dimensions - 'public service', 'nationalistic', and 'family' motivations. This construct fits with probability score of 0.327, CMIN/DF of 1.991, CFI of 1.105, and RMSEA of 0.040 .

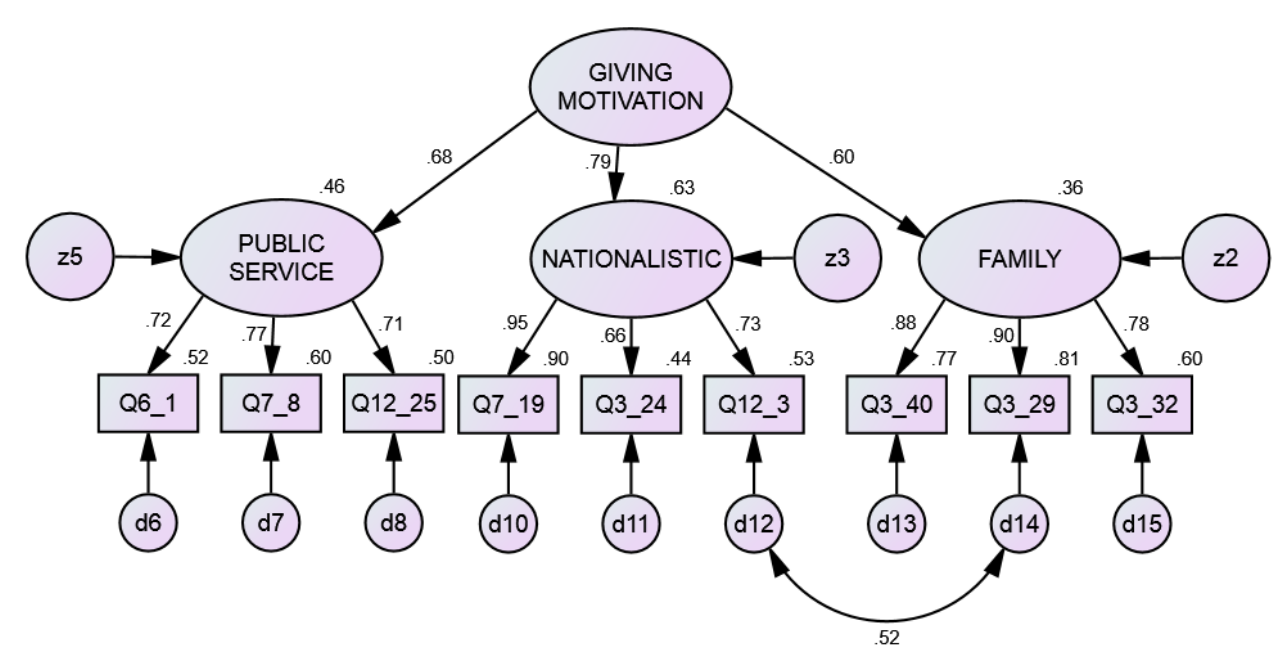

\begin{tabular}{|l|l|l|l|l|}
\hline Criteria & $\mathrm{P}$ & CMIN/DF & CFI & RMSEA \\
\hline Results & 0.327 & 1.991 & 1.105 & 0.040 \\
\hline Cut-off & $>0.05$ & $<3.0$ & $>0.95$ & $\leq 0.05$ \\
\hline
\end{tabular}

Figure 2. The fitted construct of giving motivation 
Taking/receiving and giving: A comparison of two studies on students' entrepreneurial motivation in Indonesia

\subsection{The quantitative pilot study \#2}

The following tables and figures show the results both of the factor analyses and the confirmatory factor analyses.

Exploratory factor analysis - In total, 40 indicators under nine dimensions retained during exploratory factor analysis including 'innovative' (factor loadings ranging from 0.556 to 0.906), 'hope' (factor loadings ranging from 0.699 to 0.836 ), 'ambitious' (factor loadings ranging from 0.522 to 0.841 ), 'parent' (factor loadings ranging from 0.602 to 0.730 , 'networking' (factor loadings ranging from 0.415 to 0.682 ), 'altruism' (factor loadings ranging from - 0.571 to 0.774 ), 'religious' (factor loadings ranging from 0.674 to 0.889 ), 'raw model' (factor loadings ranging from -0.422 to 0.789 ) and 'devotion' (factor loadings ranging from 0.417 to 0.759 ) motivations (please see Table 4). For the second pilot study, the Cronbach's alpha scores are ranging from 0.622 (innovative motivation dimension) to 0.932 (devotion motivation dimension). Therefore, all dimensions are reliable (Nunnally \& Bernstein, 1994) and included for further analysis.

\section{Table 4}

Results of exploratory factor analysis of the second pilot study and reliability tests

\begin{tabular}{|c|c|c|c|c|c|c|c|c|c|}
\hline Indicators & & & & & & & & & \\
\hline $1 \quad$ Innovative motivation & 1 & 2 & 3 & 4 & 5 & 6 & 7 & 8 & 9 \\
\hline A5-1 To obtain my personal growth. & 0.906 & & & & & & & & \\
\hline A5-2 To be innovative by developing new ideas & 0.891 & & & & & & & & \\
\hline A5-3 To achieve a goal. & 0.853 & & & & & & & & \\
\hline A5-4 To use the skill learned in the university. & 0.820 & & & & & & & & \\
\hline A5-6 To obtain a proper life. & 0.556 & & & & & & & & \\
\hline Cronbach's alpha & 0.932 & & & & & & & & \\
\hline $2 \quad$ Hope motivation & 1 & 2 & 3 & 4 & 5 & 6 & 7 & 8 & 9 \\
\hline A8-13 To take advantage from my education background. & & 0.836 & & & & & & & \\
\hline A8-12 To realise my hope. & & 0.817 & & & & & & & \\
\hline A8-11 To realise my pray. & & 0.813 & & & & & & & \\
\hline A8-14 To realise my dream. & & 0.779 & & & & & & & \\
\hline A8-9 Don't search a job but provide it. & & 0.699 & & & & & & & \\
\hline Cronbach's alpha & & 0.869 & & & & & & & \\
\hline $3 \quad$ Ambitious motivation & & & & & & & & & \\
\hline A4-7 To travel overseas. & & & 0.841 & & & & & & \\
\hline A4-9 To get everything I want. & & & 0.790 & & & & & & \\
\hline A3-5 To get a financial freedom at the age of 30. & & & 0.700 & & & & & & \\
\hline A5-16 To enjoy my later life without a financial problem. & & & 0.643 & & & & & & \\
\hline A5-14 To get married in my young age. & & & 0.609 & & & & & & \\
\hline A2-6 To get solid vision and mission. & & & 0.581 & & & & & & \\
\hline A3-17 To get many experiences. & & & 0.522 & & & & & & \\
\hline Cronbach's alpha & & & 0.821 & & & & & & \\
\hline $4 \quad$ Parent motivation & & & & & & & & & \\
\hline A1-17 To make my parent/family happy. & & & & 0.730 & & & & & \\
\hline A1-11 To be successful more than my parent. & & & & 0.637 & & & & & \\
\hline A1-12 To become independent. & & & & 0.602 & & & & & \\
\hline Cronbach's alpha & & & & 0.786 & & & & & \\
\hline $5 \quad$ Networking motivation & & & & & & & & & \\
\hline A3-3 To build a wide business network. & & & & & 0.682 & & & & \\
\hline A3-2 To have many friends. & & & & & 0.643 & & & & \\
\hline A4-13 To support government's programs. & & & & & 0.630 & & & & \\
\hline A4-14 To continue my study abroad. & & & & & 0.579 & & & & \\
\hline A6-1 To increase my social status. & & & & & 0.455 & & & & \\
\hline A3-4 To be proud by having my own business. & & & & & 0.415 & & & & \\
\hline Cronbach's alpha & & & & & 0.835 & & & & \\
\hline $6 \quad$ Altruism motivation & & & & & & & & & \\
\hline A3-16 To employ other people. & & & & & & -0.774 & & & \\
\hline A3-15 To motivate others to be a successful entrepreneur. & & & & & & -0.722 & & & \\
\hline A3-10 To own an achievement. & & & & & & -0.720 & & & \\
\hline A4-15 To take advantage of my creative talent. & & & & & & -0.571 & & & \\
\hline Cronbach's alpha & & & & & & 0.794 & & & \\
\hline $7 \quad$ Religious motivation & & & & & & & & & \\
\hline A4-2 To take my parent to the pilgrimage of hajj. & & & & & & & 0.889 & & \\
\hline A7-8 To go to the pilgrimage of hajj using my own money. & & & & & & & 0.690 & & \\
\hline A1-24 To give other people. & & & & & & & 0.446 & & \\
\hline Cronbach's alpha & & & & & & & 0.674 & & \\
\hline
\end{tabular}


Table 4 ... continued

\begin{tabular}{|c|c|c|c|c|c|c|c|c|c|}
\hline Indicators & & & & & & & & & \\
\hline Raw model motivation & 1 & 2 & 3 & 4 & 5 & 6 & 7 & 8 & 9 \\
\hline A2-5 Being an entrepreneur is cool. & & & & & & & & -0.789 & \\
\hline A2-4 Inspired by my parent. & & & & & & & & -0.769 & \\
\hline A5-10 To build my good name. & & & & & & & & -0.422 & \\
\hline Cronbach's alpha & & & & & & & & 0.643 & \\
\hline Devotion motivation & & & & & & & & & \\
\hline A1-3 To compete with other people. & & & & & & & & & 0.759 \\
\hline A1-4 To socialise with other people. & & & & & & & & & 0.607 \\
\hline A1-18 To build a business to pass on. & & & & & & & & & 0.451 \\
\hline A1-23 To buy my parent a house. & & & & & & & & & 0.417 \\
\hline Cronbach's alpha & & & & & & & & & 0.622 \\
\hline
\end{tabular}

Note. Indicators in italic were dropped during confirmatory factor analysis later

Confirmatory factor analysis - Furthermore, observing the dimensions produced by exploratory factor analysis, the authors consider not using TRG for the second pilot study. The most appropriate grouping for this is intrinsic ('innovative', 'hope', and 'ambitious') and extrinsic motivations ('parent', 'networking', 'altruism', 'devotion', 'religious', and 'social interaction'). Using confirmatory factor analysis, the construct of intrinsic motivation achieves a fitted model with three dimensions retain: 'innovative' - four indicators; 'ambitious' four indicators; and 'raw model' - two indicators. This construct has probability score of 0.244, CMIN/DF of 1.161, CFI of 0.995, and RMSEA of 0.030 .

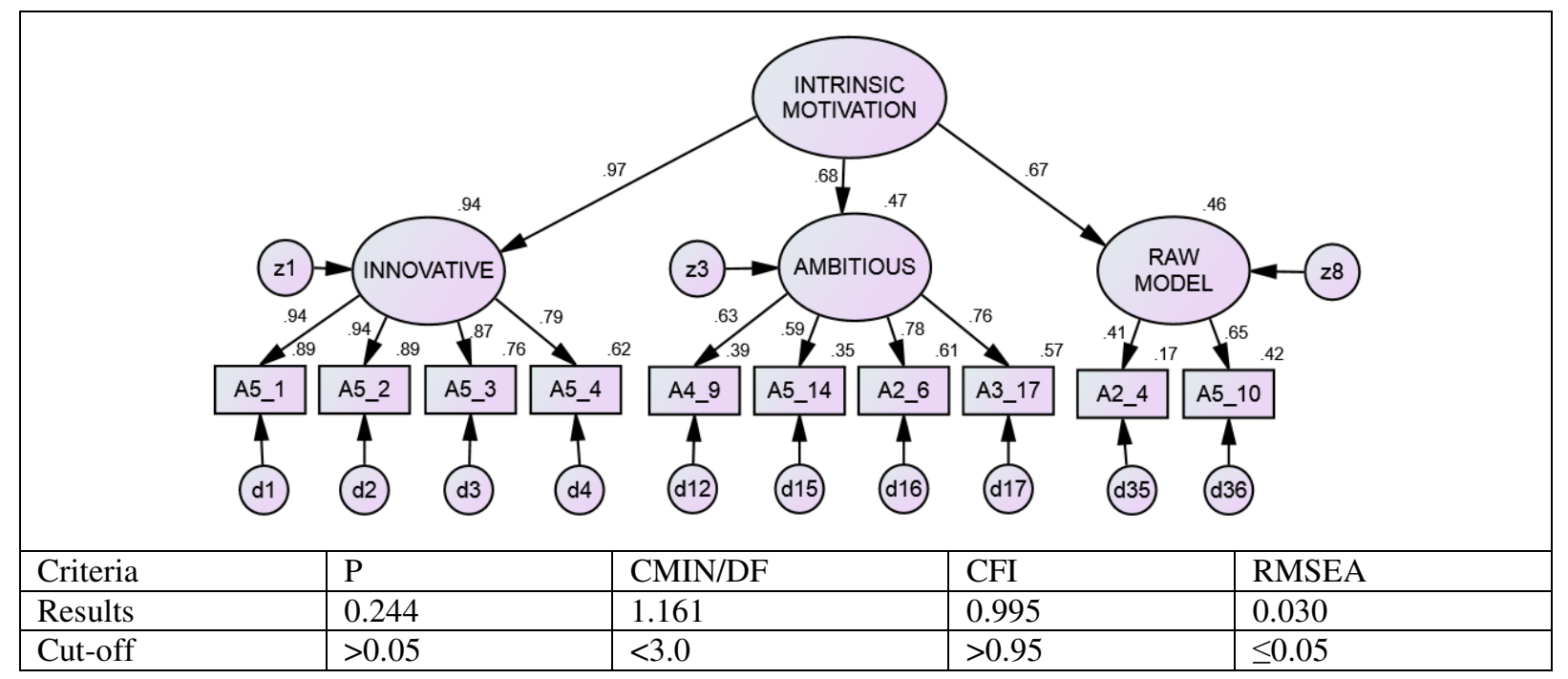

Figure 3. Confirmatory factor analysis of intrinsic motivation

The extrinsic motivation construct has five survival dimensions including 'parent' (two indicators), 'networking' (three indicators), 'altruism' (two indicators), 'devotion' (two indicators), and 'religious' (two indicators). The construct fits with probability score of 0.105, CMIN/DF of 1.292, CFI of 0.982, and RMSEA of 0.046 .

\section{Discussion and conclusion}

This study carries out some innovations. Firstly, the findings carry out a clear insight that different samples might have different findings. In the first pilot test, samples with an entrepreneurial education are motivated by taking/receiving and giving aspects. The taking/receiving motivation variable consists of three dimensions, i.e. 'safety', 'creativity', and 'time flexibility'. Amabile (1997) mentioned that entrepreneurial creativity exists and is a part of motivation. Furthermore, the giving motivation consists of 'public service', 'nationalistic', and 'family' dimensions. As mentioned earlier, this taking/receiving and giving (TRG) motivations approach is adapted from a study undertaken by Suhud (2014). The first pilot study supports Suhud's even though in two different study fields. With these two evidences the authors conclude that TRG motivations might work if samples have an experience relating to the research topic. 


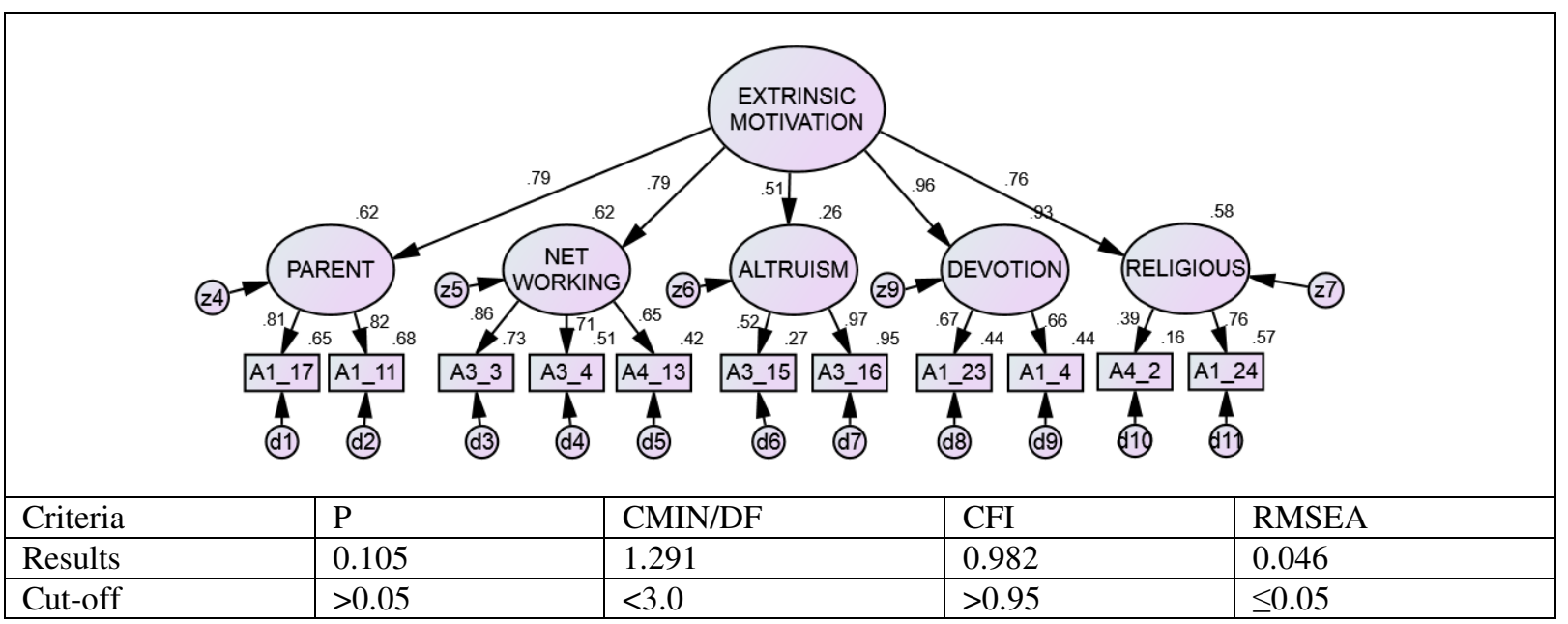

Figure 4. Confirmatory factor analysis of extrinsic motivation

Secondly, the second pilot study involved samples without an entrepreneurial education. Based on the findings, students' motivations indicate intrinsic and extrinsic motivations. These findings were supported by previous researchers like Amabile (1997), Carsrud and Brännback (2011), Cachon et al. (2013), and (Kauanui et al. (2003).

Thirdly, the two quantitative pilot studies show that motivation is not a single variable. This finding also support the previous study conducted by Suhud (2014). Contrary, most researchers in the entrepreneurial field, for example, Moses (2014), Aziz, Friedman, and Sayfullin (2012), Fatoki (2010), and Yusof et al. (2014) who applied motivation in their works treated motivation as not multiple variables. This makes sense because in this work, the authors utilised structural equation model so that there was an opportunity to analyse data as far as they could.

Fourthly, looking at the indicators resulted both in the qualitative and quantitative studies, there is a typical portrait of Indonesia as the most Muslim populated country: religious motivation. Religious value or motivation may be included by existing researchers, for example, Nwankwo and Gbadamosi (2013), Balog, Baker, and Walker (2014), and Dougherty et al. (2013) in their studies. However, what makes this study different with others that the findings include "the Prophet's sunnah (anything that was suggested and recommended by the Prophet Muhammad)", "to be like Mohammad the Prophet having own business", "to promote the good name of Islam", "to realise my pray", "to go to the pilgrimage of hajj using my own money", and "to take my parent to go to the pilgrimage of hajj".

Future studies may apply the separation of motivation as not a single variable and consider them to be included in existing theories, such theory of reasoned action and theory of planned behaviour. For academic entrepreneurs - those who teach and/or organize an entrepreneurial-based institutions - government entrepreneur, Ciputra (2007) or any parties who have a concern on entrepreneurial education for students, knowing and understanding these kind of students' motivation would lead to a strategy how to attract students to be a young entrepreneur. The strategy may include applying the right promotional tools, such as advertising, public relations/publicity, exhibition, and electronic word of mouth (Belch \& Belch, 2003; Kotler \& Keller, 2013).

\section{References}

Amabile, T. M. (1997). Entrepreneurial creativity through motivational synergy. The Journal of Creative Behavior, 31(1), 18-26. http://dx.doi.org/10.1002/j.2162-6057.1997.tb00778.x

Aziz, N., Friedman, B., \& Sayfullin, S. (2012). Motives and perceived problems of students as aspiring entrepreneurs: Differences across the Kyrgyzstan, Georgia, and the United States. International Journal of Business and Social Science, 3(13), 102-113. 
Purwana, D., Suhud, U., \& Arafat, Y. M.

Balog, A. M., Baker, L. T., \& Walker, A. G. (2014). Religiosity and spirituality in entrepreneurship: a review and research agenda. Journal of Management, Spirituality \& Religion (ahead-of-print), 1-28.

Basu, A., \& Altinay, E. (2002). The interaction between culture and entrepreneurship in London's immigrant businesses. International Small Business Journal, 20(4), 371-393. http://dx.doi.org/10.1177/0266242602204001

Belch, G. E., \& Belch, M. A. (2003). Advertising and promotion: An integrated marketing communications perspective. New York: The McGraw- Hill.

Bellotti, F., Berta, R., De Gloria, A., Lavagnino, E., Antonaci, A., Dagnino, F., et al. (2014). Serious games and the development of an entrepreneurial mindset in higher education engineering students. Entertainment Computing. http://dx.doi.org/10.1016/j.entcom.2014.07.003

Benzing, C., Chu, H. M., \& Kara, O. (2009). Entrepreneurs in Turkey: A factor analysis of motivations, success factors, and problems. Journal of Small Business Management, 47(1), 58-91. http://dx.doi.org/10.1111/j.1540-627X.2008.00262.x

Berthold, N., \& Neumann, M. (2008). The motivation of entrepreneurs: Are employed managers and self-employed owners different? Intereconomics, 43(4), 236-244. http://dx.doi.org/10.1007/s10272-008-0256-9

Biro Pusat Statistik (Central Bureau of Statistics). (2012). Table of 1997-2012 Micro, Small, and Medium Sized Enterprises (in Bahasa Indonesia0 (Publication. Retrieved January 3, 2015, from Biro Pusat Statistik: http://www.bps.go.id/tab_sub/view.php?kat=2\&tabel=1\&daftar=1\&id_subyek=13\&notab=45

Cachon, J.-C., Codina, J. B., Eccius-Wellmann, C., McGraw, E., \& Myers, D. A. (2013). Entrepreneurial motives and performance: Evidence from North America. Journal of Management, 14(3), 51.

Carsrud, A., \& Brännback, M. (2011). Entrepreneurial motivations: What do we still need to know? Journal of Small Business Management, 49(1), 9-26. http://dx.doi.org/10.1111/j.1540-627X.2010.00312.x

Catterall, M., \& Ibbotson, P. (2000). Using projective techniques in education research. British Educational Research Journal, 26(2), 245-256. http://dx.doi.org/10.1080/01411920050000971

Ciputra. (2007). Entrepreneurial education for solve poverty and jobless problems in Indonesia (in Bahasa Indonesia). Jakarta

De Silva, L. R. (2010). Business start-up and growth motives of entrepreneurs: A case in Bradford, United Kingdom: Manchester Business School.

Donoghue, S. (2000). Projective techniques in consumer research. Journal of Family Ecology and Consumer Sciences, 28(1), 47-53.

Dougherty, K. D., Griebel, J., Neubert, M. J., \& Park, J. Z. (2013). A religious profile of American entrepreneurs. Journal for the Scientific Study of Religion, 52(2), 401-409. http://dx.doi.org/10.1111/jssr.12026

Duval-Couetil, N. (2013). Assessing the impact of entrepreneurship education programs: Challenges and approaches. Journal of Small Business Management, 51(3), 394-409. http://dx.doi.org/10.1111/jsbm.12024

Fatoki, O. O. (2010). Graduate entrepreneurial intention in South Africa: motivations and obstacles. International Journal of Business and Management, 5(9), p87.

Fatoki, O. O., \& Patswawairi, T. (2012). The motivations and obstacles to immigrant entrepreneurship in South Africa. Journal of Social Sciences, 32(2), 133-142.

Gamage, H. R., Cameron, D., \& Woods, E. (2003). Are Sri Lankan entrepreneurs motivated by the need for achievement. Paper presented at the 9th international conference on Sri Lanka Studies.

Gray, K. R., Foster, H., \& Howard, M. (2006). Motivations of Moroccans to be entrepreneurs. Journal of Developmental Entrepreneurship, 11(04), 297-318. http://dx.doi.org/10.1142/S1084946706000507

Hair Jr., J. F., Black, W. C., Babin, B. J., Anderson, R. E., \& Tatham, R. L. (2006). Multivariate data analysis (6 ed.). New Jersey: Prentice-Hall, Inc.

Holmes-Smith, P. (2010). Structural equation modeling: From the fundamentals to advanced topics. Melbourne: SREAMS (School Research Evaluation and Measurement Services)

Jones, P., Beynon, M. J., Pickernell, D., \& Packham, G. (2013). Evaluating the impact of different training methods on SME business performance. Environment and Planning C: Government and Policy, 31(1), 56-81. http://dx.doi.org/10.1068/c12113b

Karimi, S., Biemans, H. J. A., Lans, T., Chizari, M., \& Mulder, M. (2014). The Impact of entrepreneurship education: A study of Iranian students' entrepreneurial intentions and opportunity identification. Journal of Small Business Management. http://dx.doi.org/10.1111/jsbm.12137

Kauanui, S. K., Ashley-Cotleur, C., \& Solomon, G. (2003). Parental and gender influence on entrepreneurs intentions, motivation, and attitudes. Paper presented at the Proceedings for the United States Association for Small Business and Entrepreneurship Conference.

Keat, Y., \& Ahmad, O. S. (2012). A study among university students in business start-ups in Malaysia: 
Taking/receiving and giving: A comparison of two studies on students' entrepreneurial motivation in Indonesia

Motivations and bbstacles to become entrepreneurs. International Journal of Business and Social Science, 3(19), 181-192.

Kompf, M. (2012). Entreplexity ${ }^{\circledR}=$ Entrepreneurship + complexity: The writing and thoughts of Gene Liczkiw: Springer Science and Business Media.

Kotler, P., \& Keller, K. L. (2013). Marketing management (14 ed.). Boston: Pearson.

Moses, C. L. (2014). Women entrepreneurship: A study of the relationship between motivation and type of business ownership. Online International Journal of Arts and Humanities, 3(8), 126-133.

Neneh, B. N. (2014). An assessment of entrepreneurial intention among university students in Cameroon. Mediterranean Journal of Social Sciences, 5(20), 542.

Nunnally, J. C., \& Bernstein, I. H. (1994). Psychometric theory (3 ed.). New York: McGraw-Hill.

Nwankwo, S., \& Gbadamosi, A. (2013). Faith and entrepreneurship among the British African-Caribbean: Intersections between religious and entrepreneurial values. Journal of Small Business and Enterprise Development, 20(3), 618-633. http://dx.doi.org/10.1108/JSBED-04-2013-0066

Osman, I., Ahmad, N. H., Ahmad, Z. A., Husin, A., Bakar, S. A., \& Tanwir, N. D. (2010). Understanding motivation, empowerment and sustainability outcomes of women homestay entrepreneurs in West Malaysia. A preliminary analysis. Retrieved from Universiti Sains Malaysia: http://eprints.usm.my/22203/1/Understanding_Motivation_Empowerment.pdf

Piperopoulos, P., \& Dimov, D. (2014). Burst bubbles or build steam? Entrepreneurship education, entrepreneurial self-ffficacy, and entrepreneurial intentions. Journal of Small Business Management. http://dx.doi.org/10.1111/jsbm.12116

Robichaud, Y., Cachon, J.-C., \& Haq, R. (2010). Motives, success factors, and barriers among Canadian female entrepreneurs: The case of Greater Sudbury. Entrepreneurial practice review, 1(2), 36-65.

Samuel, Y. A., Ernest, K., \& Awuah, J. B. (2013). An assessment of entrepreneurship intention among Sunyani Polytechnic Marketing students. International Review of Management and Marketing, 3(1), 37-49.

Shane, S., Locke, E. A., \& Collins, C. J. (2003). Entrepreneurial motivation. Human resource management review, 13(2), 257-279. http://dx.doi.org/10.1016/S1053-4822(03)00017-2

Singh, K. P. (1993). Women entrepreneurs: Their profile and motivation. Journal of Entrepreneurship, 2(1), 47-58. http://dx.doi.org/10.1177/097135579300200103

Solesvik, M. Z. (2013). Entrepreneurial motivations and intentions: Investigating the role of education major. Education+ Training, 55(3), 253-271. http://dx.doi.org/10.1108/00400911311309314

Stanley, C. (1987). Motivations of aspiring male and female entrepreneurs. Journal of Organizational Behavior, 8(3), 251-261. http://dx.doi.org/10.1002/job.4030080306

Stefanović, I., Ranković, L., \& Prokić, S. (2011). Entrepreneurs' motivational factors: Empirical evidence from Serbia. Serbian Journal of Management, 6(1), 73-83. http://dx.doi.org/10.5937/sjm1101073S

Suhud, U. (2014). A moment to give, no moment to take: A mixed-methods study on volunteer tourism marketing: Lap Lambert Academic Publishing.

Ullah, H. (2011). The impact of owner psychological factors on entrepreneurial orientation: Evidence from Khyber Pakhtunkhwa-Pakistan. International Journal of Education and Social Sciences (IJESS), 1(1).

Yusof, K. N. C. K., Jaffar, R., Harun, M. J. A. B., \& Tahir, I. M. (2014). Motivational factors and obstacles to entrepreneurial intention among business students. Australian Journal of Basic \& Applied Sciences, $8(5), 41-50$.

Zhu, L., \& Chu, H. M. (2010). Motivations, Success Factors and Problems Encountered by Chinese Women Entrepreneurs: A Factor Analysis. International Review of Business Research Papers, 6(5), 164-180.

Zimmerman, M. A., \& Chu, H. M. (2013). Motivation, success, and problems of entrepreneurs in Venezuela. Journal of Management, 14(2), 76-90. 
Purwana, D., Suhud, U., \& Arafat, Y. M. 